\title{
MODEL LATIHAN IMAGERY SEBAGAI PENDUKUNG KETEPATAN WAKTU PENCAK SILAT KATEGORI TUNGGAL, GANDA DAN REGU.
}

\author{
Bayu Iswana \\ Pendidikan Olahraga, Universitas PGRI Palembang, Indonesia \\ e-mail: bayusuroso94@univpgri-palembang.ac.id
}

\begin{abstract}
Abstrak
Penelitian ini bertujuan untuk menghasilkan Model latihan imagery sebagai pendukung ketepatan waktu pencak silat kategori tunggal, ganda, regu (TGR). Metode dalam penelitian ini adalah Research And Development yang menghasilkan model latihan imagery berbentuk buku petunjuk pelaksanaan latihan Cognitif Specific, Motivational Specific, Motivational General Arosual, Motivational General. Subyek penelitian adalah pelatih dan atlet tunggal, ganda, regu PPLD pencak silat kabupaten Musi Banyuasin, Provinsi Sumatra Selatan. Desain penelitian yang digunakan dalam penelitian ini 1. potensi masalah, 2. pengumpulan data, 3. produk desain, 4. validasi desain, 5. revisi desain, 6. uji coba produk kecil, 7. revisi produk , 8. uji coba produk besar, 9. revisi produk, 10. produk masal. Validasi dilakukan terhadap beberapa ahli pencak silat yang ber sertifikat Nasional baik wasit maupun pelatih. Hasil penelitian menunjukan bahwa ahli memberikan penilaian sebesar $80 \%$ terhadap seluruh draf produk yang dilakukan validasi dan uji coba. Ini menunjukan bahwa produk model latihan imageri sebagai pendukung ketepatan waktu pencak silat kategori tunggal, ganda, regu dapat di gunakan sebagai model latihan yang efektif.
\end{abstract}

Kata-kata kunci : Model, latihan Imagery, pencak silat tunggal, ganda, regu

\section{Abstract}

This study aims to produce a model of imagery training as a support for the timeliness, of pencak silat in the category of single, double, team (TGR). The method in this study is Research and Development that produces imagery models in the user guide for Special Cognitive Practices, Motivational Specific, Motivational General Arosual, Motivational General. Subjects were coach and single, double, and team kategories PPLD pencak silat Musi Banyuasin regency, South Sumatra Province. The research design used in this study was 1, potential problems, 2 data collection, 3 product designs, 4 design validations, 5 design revisions, 6 small product trials, 7 product revisions, 8 large product trials, 9 product revisions, 10 products mass. Validation was carried out on several martial arts experts who had National certificates, both referees and trainers. The results of the study show that experts give an $80 \%$ assessment of all product drafts that are validated and tested. This shows that the imagery training model products support the timeliness of pencak silat single, double and team category can be used as an effective exercise model.

Keywords : Model, Imagery training, single, multiple martial arts, team 


\section{Pendahuluan}

Pertandingan pencak silat kategori, tunggal, ganda, regu $(T, G, R)$ merupakan salah satu kategori yang selalu dipertandingkan dalam event olahraga seperti POPNAS, POMNAS, PON dan SEA GAMES. Pencak silat kategori ini sering disebut kalangan masyarakat sebagai pencak silat Seni. Dikatakan pencak silat seni, karena dalam proses penilaian penentuan kemenangan menonjolkan keelokan gerak, keserasian gerak, keindahan gerak, keluwesan gerak, kemantapan gerak, dan ketepatan waktu. Pencak silat kategori TGR menjadi salah satu andalan perolehan medali dalam berbagai event Internasional. Beberapa event dalam kurun 10 tahun terakhir kategori ini selalu merebut medali emas di sea games. Perolehan medali yang di dapat dalam event Internasional Sea Games tahun 2017, 1 emas dari beregu putra, 1 perak ganda putra, dan 1 perak tungal putra Indonesia. Karakteristik penilaian yang menonjol dalam pertandingan ini salah satunya menggunakan ketepatan waktu dalam setiap peragaan jurus yang sudah di tentukan, terkecuali ganda yang mengharuskan pesilat membuat rangkaian jurus sendir, itupun harus mencapai ketepatan waktu dalam 3 menit.

Menurut Peraturan Pertandingan pencak silat IPSI MUNAS Tahun 2012 pasal 10" bahwa dalam setiap peragaan jurus mendapatkan pengurangan nilai apabila:

(a), Peragaan kurang atau lebih dari 3 (tiga) menit penampilan kurang atau lebih dari 10 (sepuluh) s/d 15 (lima belas) detik dikenakan pengurangan nilai 10 untuk usia dini dan pra remaja, (b) Penampilan kurang atau lebih dari 5 (lima) s/d 15 (lima belas) detik dikenakan pengurangan nilai 10 untuk remaja, dewasa dan pendekar, (c) Penampilan kurang atau lebih dari 16 (enam belas) detik s/d 30 (tiga puluh) detik dikenakan pengurangan nilai 15, (d) Penampilan kurang atau lebih dari 30 (tiga puluh) detik dikenakan pengurangan nilai 20.

Kurang atau lebihnya waktu dalam pertandingan kerap kali menjadi bagian yang sangat di khawatirkan oleh pelatih dan atlet. Dalam kenyataannya banyak kasus yang terjadi pada saat peragaan, atlet mengalami gangguan psikologis yang berasal dari penonton, lawan dan beberapa aturan sehingga atlet mengalami kelebihan bahkan kekurangan waktu dalam proses peragaan jurus. Hal ini secara langsung mengganggu dan merugikan nilai yang deperoleh atlet. Tidak menutup kemungkinan peragaan yang indah, kemantapan gerak, dan kebenaran jurus dalam setiap gerakan terkadang dikalahkan oleh faktor ketepatan waktu. Hal ini sangat disayangkan karena atlet yang secara kualitas gerakan baik namun dapat dikalahkan oleh ketepatan waktu.

Ari Septiyanto (2016) Menyatakan berdasarkan Hasil penelitian menunjukkan ada perbedaan hasil floating service antara atlet yang memiliki konsentrasi tinggi dan konsentrasi rendah, atlet dengan konsentrasi tinggi lebih baik dibandingkan dengan konsentrasi rendah terhadap hasil floating service, dan ada interaksi antara metode latihan internal imagery dan external imagerydan konsentrasi (rendah dan tinggi) terhadap hasil floatingservice bagi atlet. Satrio Anggoro P W (2016) juga menyatakan terdapat pengaruh yang signifikan antara latihan mental imagery yang diberikan terhadap hasil tembakan atlet menembak Jawa Barat dengan nilai t sebesar -2,896 dengan nilai signifikansi 0,018<0,05, Atlet menembak akan memiliki mental yang baik apabila diberikan latihan mental imagery karena atlet menembak akan memiliki kepercayaan diri dan motivasi tinggi yang dapat membantu membuat kondisi atlet untuk berkonsentrasi agar mendapatkan fokus yang baik. Hal senada juga di sampaikan oleh Pratiwi (2017) yang menyatakan Hasil uji hipotesis menunjukkan bahwa ada perbedaan pengaruh mental imagery training terhadap kecemasan bertanding pada atlet BKMF pencak silat Fakultas IImu Keolahragaan Universitas Negeri Makassar.

Septiyan (2016) juga menyatakan terdapat perbedaan pengaruh antara metode latihan internal imagery dan external imagery terhadap hasil floating service, metode latihan internal imagery lebih baik dibandingkan dengan metode latihan external imagery. Candra Alfi (2016) juga menyatakan berdasarkan hasil penelitian yang telah ditemukan bahwa pendekatan latihan menendang menggunakan imagery dapat mempengaruhi akurasi tendangan ke gawang pemain sepakbola siswa SMA Negeri 01 Kampar Kiri Kabupaten Kampar. Dengan kata lain dapat diartikan bahwa latihan ini dapat dipergunakan untuk 
meningkatkan akurasi tendangan ke gawang pemain Klub sepakbola siswa SMA Negeri 01 Kampar Kiri Kabupaten Kampar.

Melihat permasalahan dan fakta yang terjadi dilapangan perlu adanya suatu pengembangan model latihan imagery sebagai pendukung ketepatan waktu pencak silat kategori tunggal, ganda, regu (TGR). Model latihan imagery ini berbentuk Cognitif Specific, Motivational Specific, Motivational General Arosual, Motivational General.

Adanya pengembangan model latihan imagery Sebagai pendukung ketepatan waktu pencak silat kategori TGR merupakan jawaban yang sesuai dengan permasalahan yang dihadapi oleh pelatih dan atlet.

\section{Metode}

Penelitian ini menggunakan metode penelitian dan pengembangan (Research and Development) merupakan metode penelitian yang digunakan untuk menghasilkan produk tertentu, dan menguji keefektifan produk tersebut. Penelitian pengembangan ini dilakukan untuk menghasilkan sebuah model latihan imagery sebagai pendukung ketepatan waktu pencak silat kategori tunggal, ganda regu.

Adapun langkah-langkah penelitian pengembangan menurut sugiyono (2010: 407) sebagai berikut:

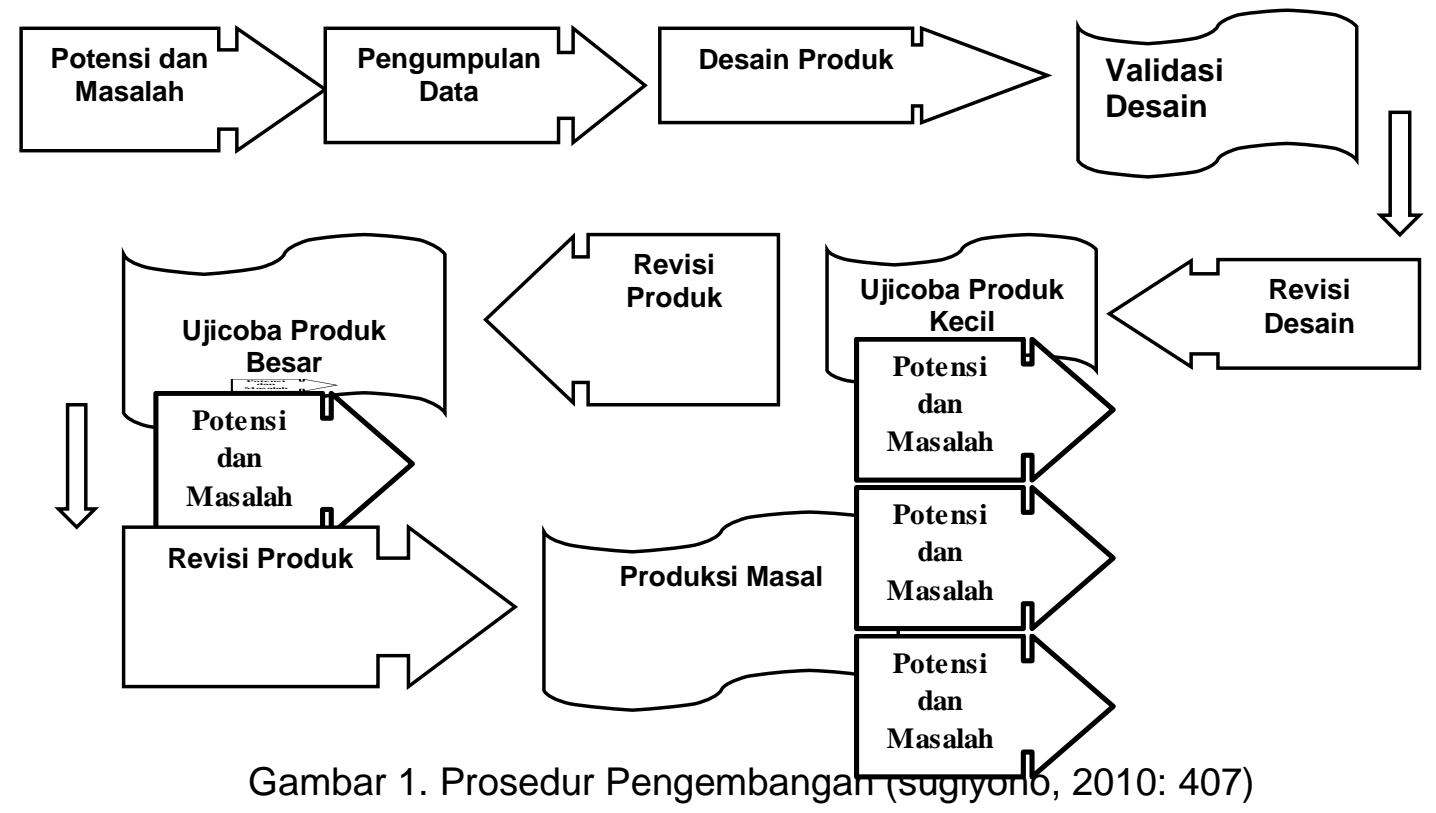

Perkembangan pencak silat di indonesia pada saat ini sangat menonjol. Dilihat dari prestasi yang didapatkan saat Multi-event internasional, pencak silat mampu memberikan sumbangan medali emas setiap penyelenggaraannya. Medali emas didapat dari nomor tanding dan seni tunggal, ganda serta beregu. Pada tahun 2011, 2013, 2015 dan terakhir 2017, cabang olahraga pencak silat selalu menyumbangkan medali emas. Ini salah satu bukti bahwa pencak silat merupakan salah satu cabang olahraga andalan pada setiap event olahraga. Pembinaan atlet guna regenerasi dalam Kategori tunggal, ganda, regu dilakukan sejak dini. Permasalahan muncul ketika atlet mulai mengenal pertandingan, banyak kasus bahwa ketepatan waktu saat pertandingan melebihi dan bahkan ada yang kurang dari batas waktu yang sudah di tentukan. Inilah salah satu dasar penulis untuk membuat model latihan imagery sebagai pendukung ketepatan waktu pencak silat kategori tanding, ganda, regu ( TGR).

Proses pengumpulan informasi diawali dengan peneliti melakukan pengumpulan permasalahan yang dihadapi pelatih dan atlet pencak silat kategori Tunggal, ganda dan 
regu. Informasi didapat dari hasil pengamatan peneliti terhadap masalah yang kerap terjadi di pertandingan pelajar, dewasa di beberapa event kejuaraan daerah di sumatra selatan. Proses selanjutnya dilakukan pengumpulan informasi lebih lanjut dengan melakukan studi pustaka tentang bagaimana metode yang sesuai guna memecahkan masalah yang terjadi. Metode latihan imagery merupakan salah satu metode yang sangat sesuai dilakukan dalam proses latihan guna mendukung dalam proses pencapaian ketepatan waktu saat atlet bertanding. Diharapkan dengan adanya bermacam-macam model latihan melalui metode latihan imagery pelatih tidak lagi mengalami kesulitan dalam menangani atletnya.

Desain Produk

Peneliti menyusun beberapa konsep suatu produk yang mengacu pada teori latihan imagery. Model latihan imagery yang akan di kembangkan adalah Cognitif Specific, Motivational Specific, Motivational General Arosual, Motivational General Mastery. Model akan dibuatkan buku petunjuk pelaksanaan dan konsep dari latihan yang didalamnya memuat kasus kasus yang menghambat proses pertandingan dan hal hal yang mendukung atlet untuk dapat memperagakan jurus secara maksimal sesuai dengan aturannya yang mengarah pada proses ketepatan waktu pertandingan. Serta CD yang memuat suara caci maki penonton, sorakan penonton, yang sesuai dengan suara yang terdengar saat pertandingan pencak silat kategori Tunggal, Ganda, Regu dilaksanakan.

\section{Teknik Pengumpulan Data}

Teknik pengumpulan data apabila peneliti ingin melakukan studi pendahuluan untuk menemukan permasalahan yang diteliti dan juga apabila peneliti ingin mengetahui hal-hal dari responden yang lebih mendalam, teknik pengumpulan data ini mendasarkan dari pada laporan tentang diri sendiri atau self-report, atau setidaknya pengetahuan dan atau keyakinan pribadi , ( sugiyono, 2010: 231). Dalam hal ini teknik pengumpulan data digunakan untuk mengumpulkan kelemahan dan kekurangan produk yang dihasilkan yang di berikan kepada pelatih pencak silat. Sehingga produk dapat memenuhi aspek kebutuhan secara menyeluruh.

Skala nilai digunakan untuk menilai model latihan imagery sebagai pendukung ketepatan waktu pencak silat kategori tunggal, ganda, regu. Setelah ahli memberikan persetujuan serta menilai model latihan imagery sebagai pendukung ketepatan waktu pencak silat kategori tunggal, ganda, regu yang mengacu pada skala nilai, baru model latihan dapat diujicobakan. Skala nilai yang dimaksud adalah kategori berskala 4, 3, 2,1. Dalam skala rating responden tidak akan menjawab salah satu jawaban kualitatif yang telah disediakan tetapi menjawab salah satu jawaban kuantitatif yang telah disediakan ( sugiyono, 2010: 98).

\section{Teknik Analisis Data}

Teknik analisis data yang digunakan yaitu analisis deskriptif kuantitatif dan kualitatif. Analisis deskriptif kuantitatif digunakan untuk menganalisis data yaitu: (a) data skala nilai berupa hasil penilaian para ahli/pakar terhadap model latihan sebelum draf diujicobakan, (b) data hasil observasi para ahli/pakar terhadap model latihan. Sedangkan analisis deskriptif kualitatif dilakukan terhadap: (a) data masukan dan kekurangan model latihan baik setelah dilakukan uji coba ataupun sebelum. Produk model latihan dinyatakan layak untuk dilakukan uji coba apabila para ahli/pakar telah memberikan validasi dan menyatakan semua item dianggap sesuai dengan cara memberi tanda melingkari salah satu jawaban 4, 3, 2, atau 1 . Hasil penilaian terhadap item-item dijumlahkan, kemudian di total nilainya selanjutnya ditabulasikan sesuai dengan analisis rating scale.

Hasil Validasi Dimasukan Dalam Rumus sebagai berikut: 


$$
\begin{array}{ll}
\text { V }=\text { TSEV } \times 100 \% \\
\text { S-max } & \\
\text { Keterangan: } & \\
\text { V } & =\text { Validitas } \\
\text { TSEV } & =\text { Total skor empirik validator } \\
\text { S-max } & =\text { Skor maksimal yang diharapkan } \\
100 & =\text { konstanta }
\end{array}
$$

Tabel.1 Penggolongan Presentese Pengolahan Data

\begin{tabular}{ll} 
Presentase & Keterangan \\
\hline $75,01 \%-100 \%$ & Sangat valid ( dapat digunakan tanpa revisi) \\
\hline $50,01-75,00 \%$ & Cukup valid (dapat digunakan dengan revisi) \\
$25,01 \%-50,00 \%$ & Kurang valid ( tidak dapat digunakan) \\
\hline $00,00 \%-25,00 \%$ & Sangat tidak valid
\end{tabular}

(Sumber: Akbar \& Sriwiyana, 2010: 207)

\section{Hasil dan Pembahasan}

Penilaian beberapa ahli mengenai pengembangan model latihan ini sangat baik. Ahli menilai bahwa melalui video yang dilihat oleh atlet dapat memberikan sebuah transfer pengetahuan tentang gerakan gerakan yang dilakukan serta atlet dapat mengetahui kesalahan yang selama ini dilakukan. Gerakan yang benar dan mengacu pada gerak baku memberikan model latihan ini lebih specific terhadap kebutuhan latihan secara psikologis yang memberikan dampak positif tarhadap kebenaran gerak dan pencapaian ketepatan waktu saat bertanding. Ahli juga menilai bahwa model latihan ini dapat mengetahui beberapa gerakan baku jika terjadi keterlambatan waktu dan waktu yang terlalu cepat dalam setiap jurus yang dilakukan. Selain itu model ini juga sangat membantu atlet dalam melakukan latihan dalam waktu senggang dimana atlet dapat melihat model ini sesuai dengan waktu yang ada. Sesuai dengan tujuan penelitian bahwa model ini telah dilakukan revisi draf oleh para ahli dan pengujian uji coba sehingga model ini layak dijadikan sebuah model latihan imagery guna mendukung ketepatan waktu pencak silat kategori tunggal, ganda regu.

\section{Motivational Specific}

Model latihan ini mengarahkan atlet terhadap fokus tujuan gerakan yang harus dilakukan tanpa memikirkan sebuah hambatan dalam proses pertandingan. Model ini dapat dilakukan ketika latihan dan juga menjelang pertandingan. Atlet menanamkan rasa percaya diri bahwa gerakan yang dilakukan harus mantap, penuh penjiwaan, kebenaran gerak serta meyakini akan ketepatan waktu yang akan dia dapatkan ketika bertanding. Model ini sangat baik dilakukan sebagai model latihan, terbukti dari beberapa ahli memebrikan penilaian yang masuk dalam kategori sangat baik. Ahli berpendapat bahwa latihan imageri ini harus selalu dilakukan agar keyakinan terhadap tujuan akan menjadi sebuah kenyataan dalam proses bertanding.

\section{Motivational General Arosual}

Sebuah pertandingan pencak silat tidak lepas dari suasana senang, gembira dan terkadang hal yang tidak di inginkanpun terjadi. Dalam kenyataanya ada beberapa atlet ketika bertanding terlalu memikirkan hal yang buruk sehingga mempengaruhi penampilan saat bertanding. Sesuai dengan saran ahli bahwa dalam setia pertandingan sebisa mungkin suasana atlet dalam keadan senang dan gembira. Hal ini ditujukan agar secara psikologis atlet dapat mengembangkan pemikiran positifnya sehingga dalam proses bertanding dapat 
menikmati pertandingan dengan baik. Sesuai dengan penilaian ahli bahwa model latihan ini harus selalu di terapkan. Atlet justru diharuskan melakukan latihan ini agar suasana nyaman, senang dan gembira selalu dirasakan ketika akan bertanding. Ahli menilai melalui skala penialain bahwa model latihan ini sangat baik. Motivational General Arosual ini dibuat agar atlet terbiasa merasakan, mengalami, emosi suasana dalam pertandingan. Diharapkan model latihan ini akan memberikan dampak yang positif terhadap atlet dalam memperagakan penampilannya.

Motivational General Mastery latihan ini terkait dengan penguasaan situasi olahraga, seperti atlet pencak silat fokus terhadap penampilan ketika mendapat caci maki penonton. Caci maki penonton kerap kali terjadi ketika pertandingan, karena hal ini tidak dapat dihindari. Masalah muncul ketika pendukung lawan melihat penampilan seorang atlet dari kontingen yang berbeda. Saling menjatuhkan menggunakan bahasa yang sifatnya merendahkan penampilan, dengan tujuan fokus, kosentrasi terganggu dengan tujuan penampilannya menurun agar nilai dan ketepatan waktu rendah. Terjadinya kesalahan jurus dalam pertengahan peragaan akibat caci maki penonton akan berdampak terhadap kesalahan-kesalahan selanjutnya. Ketika seorang atlet mengalami kesalahan dan hilangnya fokus terhadap apa yang ditampilkan merupakan sebuah kerugian besar bagi atlet tersebut. Maka dari itu seorang atlet harus siap dengan apa yang akan terjadi dalam proses pertandingan termasuk caci maki penonton. Latihan imagery adalah salah satu bentuk agar atlet dapat mengantisipasi apa yang akan terjadi termasuk situasi yang tidak pernah dimunculkan dalam latihan sebelumnya

Motivational General Mastery.

Beberapa masukan yang diberikan oleh ahli terhadap model latihan ini diantaranya, model latihan ini harus membuat suasana atlet terbawa oleh suasana yg sesuai dengan pertandingan yang sebenarnya. Kemudian ahli memberikan evaluasi tarhadap model latihan ini yakni suara dan tahapan-tahapan yang terjadi didalam proses pertandingan harus sistematis. Hal ini dimaksudkan agar atlet dapat merasakan betapa riuh dan tegangnya suasana pertandingan pada saat itu. tujuanya adalah agar proses penerapan model latihan ini dapat sesui dengan suasana pertandingan. Setelah ahli memberikan evaluasi pada tahap uji coba dan revisi tahap akhir. Akhirnya ahli memberikan sebuah saran agar model ini harus dibiasakan terhadap atlet ketika akan bertanding. Hal ini bertujuan untuk menghidari suasana yang justru membawa atlet dalam kegelisahan yang berlebihan.

Secara umum ahli sangat menganjurkan dan model ini sangat baik untuk diberikan kepada atlet jauh-jauh hari menjelang pertandingan. Ada beberapa hal ketika dilakukan uji coba skala kecil, bahwa ada atlet yang terbawa susasana caci-maki penonton. Model ini berupa rekaman suasana bertanding yang syarat akan cacimaki penonton ketika seorang atlet akan memasuki gelanggang pertandingan dan saat atlet melakukan peragaan jurus. Namun kesimpulan dari pada model ini bahwa, model latihan ini harus terlebih dahulu dibiasakan oleh atlet hingga atlet tidak lagi terganggu dalam suasana yang sangat tidak kondusif.

\section{Simpulan dan Saran}

Model latihan imageri ini adalah salah satu cara untuk mencapai tujuan dalam pertandingan pencak silat kategori tunggal, ganda, regu. Produk model latihan ini berupa buku petunjuk pelaksanaan dan stimulus audio yang menyesuaikan dengan suara pelatih, dan suara dalam lingkup pertandingan yang sebenarnya. Model latihan ini mendorong agar atlet pencak silat kategori tunggal, ganda dan regu mampu mencapai catatan waktu yang sudah ditentukan oleh aturan IPSI yaitu tiga ( 3) menit dalam setiap peragaan jurusnya. Model ini terdiri dari 4 model latihan yang keseluruhan melatih psikologi atlet menjelang pertandingan. Dari ke empat model latihan, uji validasi ahli terhadap draf yang sudah dilakukan uji coba skala besar penilaian ahli terhadap keempatnya diatas $80 \%$. Sehingga peneliti menyimpulkan bahwa produk model latihan ini dapat digunakan sebagai latihan imagery sebagai pendukung ketepatan waktu atlet pencak silat ketegori tunggal, ganda, 
regu. Ke-empat model latihan tersebut adalah Cognitif Specific, Motivational Specific, Motivational General Arosual, Motivational General.

Peneliti memahami mengenai hasil produk akhir yang hanya sebatas membuat produk, belum melakukan desiminasi terhadap produk tersebut. Kekurangan yang lain dalam penelitian ini bahwa pengguna dalam hal ini pelatih, harus mampu memberikan keyakinan terhadap atletnya pada saat menyampaiakn bagian bagian yang tertulis dalam buku petunjuk pelaksanaan produk 1-3. Namun untuk produk yang ke 4 pelatih harus memantau bagaimana gejolak psikologis yg terjadi oleh atlet agar tidak menimbulkan transformasi negative yang diterima oleh atlet.

\section{Daftar Pustaka}

Akbar, S.\& Sriwiyana, H.2010. Pengembangan Kurikulum dan Pembelajaran IImu Pengetahuan Sosial (IPS). Yogyakarta: Cipta Media.

Ari Septiyanto dan Suharjana. 2016. Pengaruh Metode Latihan Imagery dan Konsentrasi Terhadap Ketepatan Floating Service Atlet Bola Voli. Jurnal Cakrawala Pendidikan. Volume 35, nomor 3.

Bayu Iswana.(2013). Model keterampilan gerak pencak silat anak usia 9-12 tahun. Tesis magister. Unversitas Negeri Yogyakarta. Yogyakarta.

Candra Alfi. 2016. Pengaruh Latihan Menendang menggunakan Imageri terhadap Akurasi Tendangan ke Gawang. Journal Sport Area Penjaskesrek FKIP Universitas Islam Riau. Volume 3, No 1.

Hergenhahn, B .R, Matthew H. Olson. (2008). Theories of learning: Terjemahan Teori belajar (Edisi 7). Jakarta : Prenada Media Group.

Johansyah \& Hendro.(2013). Pencak silat: edisi ketiga. Jakarta. PT. RajaGrafindo Persada.

Komarudin.(2014). Psikologi olahraga, latihan keterampilan mental dalam olahraga kompetitif. Bandung. PT Remaja Rosadakarya.

Muchamad \& faridha. (2013). Pengaruh latihan imagery terhadap hasil tembakan pada jarak 30 meter ekstrakulikuler olahraga panahan SMP Negeri 02 Bakung Blitar. Jurnal pendidikan olahraga dan kesehatan volume 01 nomor $02,454-458$. Unesa

Mulyana. ( 2013). Pendidikan pencak silat membangun jati diri dan karekter bangsa. Bandung. PT Remaja Rosadakarya.

Munas IPSI XII. (2012). Peraturan pertandingan pencak silat . Jakarta. PB IPSI.

Pratiwi, Israh. 2017. Pengaruh Mental Imagery Training Terhadap Kecemasan Bertanding Pada Atlet Bkmf Pencak Silat Fakultas IImu Keolahragaan Universitas Negeri Makassar. SPORTIVE: Journal Of Physical Education, Sport and Recreation. Vol. 1, No.2.

Satrio Anggoro Putra Wibowo, Nur Indri Rahayu. 2016. Pengaruh Latihan Mental Imagery terhadap Hasil Tembakan Atlet Menembak Rifle Jawa Barat. Jurnal Terapan IImu Keolahragaan. Vol.1, No.2. (p) 23-29.

Septiyan. 2016. Pengaruh Metode Latihan Imagery dan Konsentrasi terhadap Ketepatan menembak. Jurnal Hasil Riset. Volume 1 No.1. 
Sugiyono (2010). Metode penelitian kuantitatif kualitatif dan R\&D.Bandung. Alfabeta

Suharjana (2013). Kebugaran Jasmani. Yogyakarta . Jogja Global Media.

Syafruddin (2011). IImu kepelatihan Olahraga teori dan aplikasi dalam pembinaan olahraga. Padang. UNP Prees.

Wahyudi, Arif Firmansyah, Helmy. 2013. Penerapan Latihan Mental Imagery dalam Pelatihan Softball di Jawa Barat. Jurnal IPTEK Olahraga. vol. 15 no. 01. (p) 62-77. 